\title{
LTA Gene
}

National Cancer Institute

\section{Source}

National Cancer Institute. LTA Gene. NCI Thesaurus. Code C18424.

This gene is involved in apoptosis, immunoregulation and lymphoid tissue development. 